\title{
Law Enforcement in Ensuring the Care of Hifz Al-Nafs wa Al-Aql wa Al-Mal in the Case of a Drunk Driver
}

\author{
Wan Abdul Rahman Wan Ibrisam Fikry ${ }^{1}$ Mohamad Anas Mohamad Yaakub ${ }^{1}$, \\ Muhammad Aiman Abdull Rahim', Muhammad Haqqul Yaqin Mohd Jelani², \\ Aminuddin Ruskam ${ }^{1}$ \\ ${ }^{1}$ Academy of Islamic Civilization, Faculty of Social Science and Humanities, Universiti Teknologi Malaysia (UTM) \\ ${ }^{2}$ School of Education, Faculty of Social Science and Humanities, Universiti Teknologi Malaysia (UTM) \\ *Corresponding author. Email: mtalhah.uda@gmail.com
}

\begin{abstract}
The solution to the drunk driving behavior is urgently needed as the cases has shown a worrying increased in Malaysia. Solutions need to be implemented through all angles including the empowerment of law enforcement. A law is designed for the benefit of human beings to live a harmonious life. The law was drafted taking into account the priorities in preserving Dharuriyyat al-Khams, namely the five universal human interests in order, starting with Hifz Al-Din (religious care), Hifz Al-Nafs (life care), Hifz Al-Maal (property care), Hifz Al-'Aql (care of the mind) and Hifz Al-Nasal (care of the descendants). So, in the case of a drunk driver, it is very related to Hifz Al-Nafs, Al- $\mathrm{Aql}$ and Al-Mal. Emphasis on law enforcement is among the forms of education and resolution. This concept paper utilizes literature review for data collection. The impact of this study explains the definition of Maqasid Syariah in general as well as the enforcement of the law in the case of drunk drivers.
\end{abstract}

Keywords: Empowerment of Law, Maqasid Syariah, Legal Relations and Maqasid Syariah, Hifz al-Nafs Hifz al-'Aql and Hifz al-Mal

\section{INTRODUCTION}

Laws are designed to make it easier for people to live a social life. Marcus Tullius Cicero, a Roman philosopher stated that the happiness of a society depends on the obedience of each individual to the law.

From the Islamic point of view, compliance with the law set by the leader is final based on the clear words of Allah in surah Al-Nisa verse 59 as long as it does not conflict with the requirements of the law of Allah SWT. The basis and fundamental of the Syariah is based on the wisdom and benefits of human beings both in this world and in the hereafter. Ibn Qayyim stated that the Shari'ah is all fair and maslahat. [1]

"O you who believe, obey Allah, and obey the Messenger of Allah, and Ulil Amri (leader) from among you. And if you have disputes in certain
In the context of the knowledge of Maqasid Syariah, or the noble purpose of Islamic law, priority is given in preserving Dharuriyyat al-Khams which are the five universal human interests according to levels, starting with Hifz Al-Din (religious care), Hifz Al-Nafs (life care), Hifz Al-Maal (custody of property), Hifz Al'Aql (custody of the mind) and Hifz Al-Nasal (custody of the offspring) [2]

Following the increase in cases of road accidents caused by the negligence of drunk drivers, it is enough to say that some of the drivers are still at a low level in term of following the driving rules [3]. This sparked discussion among the national government

things, refer it to Allah and His Messenger, if you believe in Allah and the Last Day. That is better (for you) and better in the end". 
because it caused annoyance and invited concern to other users who also have the right to drive safely. [4].

Therefore, by using the literature review, this study aims to see the extent of legal enforcement in realizing Hifz Al-Nafs, Al-'Aql and Al-Mal against road and traffic users, especially in the case of drunk drivers.

\section{PROBLEM STATEMENT}

The United Nations (UN) has set a target in the Third Goal (Health and Well -Being) - which is one of the 17 Sustainable Development Goals (SDGs) - which starts in 2020, targeted to reduce by half the number of deaths and injuries resulting from road accidents from the previous year [5]. However, the reality of road accidents in Malaysia is showing a dramatic increase [6], [7].

The cause of the increase in road accident statistics is generally due to individual, environmental, and disobedient to law [8]. Individual factors were analyzed as the highest cause of accidents, while driving under the influence of alcohol or psychoactive substances was the highest contributing sub-factor. [7], [9]. In the context of intoxicated drivers, the risk begins when the level of alcohol in the blood (Blood Alcohol Concentration - BAC) begins to exist minimally, and will reach a significant level when the BAC level reaches 0.05 $\mathrm{g} / \mathrm{dl}$ [7]. On the other hand, fatal accidents also involve a lot of motorcyclists who on average consist of young people between 16 to 30 years old. [10]. This reality is increasingly worrying with the phenomenon of alcohol consumption among young Malaysians due to the ease of access to alcohol in stores. [11].

In addition, the cause of this increasing accident rate can also be seen through incompetent law enforcement based on traffic summons issuance statistics between 2009-2013 which is only at a rate of 35\%, [10]. In reality, optimal law enforcement is a method that has proven to be effective in preserving lives, property damage as well as lowering road accident statistics as has been implemented in OP Selamat [12]. Therefore, Maqasid Syariah's discussion on measures in addressing the issue of drunk drivers through the enforcement of traffic laws which emphasizes the importance of preserving life (Hifz an-Nafs) and property (Hifz al-Mal) is a good start. This discussion will provide some proposed frameworks and solutions to law enforcement to reduce the rate of road accidents involving drunk drivers.

\section{LAW ENFORCEMENT AGAINST DRUNK DRIVERS}

In the context of the case of drunk drivers, the enforcement of the law is clearly enshrined in section 44 of the Road Transport Act 1987 (Act 333) [13] which states one of the offenses in driving namely:
Driving while under the influence of intoxicating liquor or drugs.

The provisions of Section 44 state that it is an offense to be unable to control a vehicle preferably due to the influence of intoxicating liquor or drugs, or because the alcohol content in the body exceeds the prescribed limit resulting in death or injury to others if convicted is punishable by imprisonment, fine and disqualification of a driving license for a certain period [13].

Recently, in September 2020, the Senate passed the Road Transport (Amendment) Bill (RUU) 2020 following the increase in deaths due to road accidents caused by the negligence of drunk drivers [14]. Table 1 compares the punishment for a drunk driver who causes death in the provisions of Section 44 of the Road Transport Act 1987 (Act 333) between the updated version of February 2013 and the latest 2020 Amendment.

Based on table 1, the minimum rate of punishment for drunk drivers increased dramatically. The prison sentence was increased more than three times from 3 years to a minimum of 10 years imprisonment. The minimum amount of fine will be increased from RM8,000 to RM50,000 while offenders will be disqualified for a driving license for 10 years compared to only 5 years in the updated version of 2013. Amendment 2020 also detailing the different rates for 
Table 1. Types of updated penalties and fines

\begin{tabular}{|c|c|c|c|}
\hline Bil. & $\begin{array}{c}\text { Tpes of } \\
\text { Punishment }\end{array}$ & 1 Februari 2013 & Amendment 2020 \\
\hline 1 & Prisonment & $\begin{array}{l}\text { Not less than } 3 \text { years and not more than } 10 \\
\text { years }\end{array}$ & $\begin{array}{l}10 \text { to } 15 \text { years for first time offenses } \\
15 \text { to } 20 \text { years for second and subsequent offenses. }\end{array}$ \\
\hline 2 & Fine & $\begin{array}{l}\text { Not less than RM8 thousand and not more } \\
\text { than RM20 thousand. }\end{array}$ & $\begin{array}{l}\text { RM50 thousand to RM100 thousand for first time offense } \\
\text { RM100 thousand to RM150 thousand for second and subsequent } \\
\text { offenses. }\end{array}$ \\
\hline 3 & $\begin{array}{l}\text { Disqualified } \\
\text { driving } \\
\text { license }\end{array}$ & $\begin{array}{l}\text { Not less than } 5 \text { years for first time offense } \\
\text { Not less than } 10 \text { years for second and } \\
\text { subsequent offenses. }\end{array}$ & $\begin{array}{l}10 \text { years for first time offense } \\
20 \text { years for second and subsequent offenses. }\end{array}$ \\
\hline
\end{tabular}

each sentence based on the frequency with which the offense was committed.

\section{LEGAL ENFORCEMENT IN LINE WITH THE DEMANDS OF MAQASID SYARIAH}

\subsection{Definition of Maqasid Syariah}

Maqasid is an Arabic word derived from the word maqsad which carries the meaning of purpose or objective which means based on actual statements or facts [15]. Shariah is all that was revealed by Allah SWT to mankind through His Messenger Prophet Muhammad SAW [16]. According to al-Raisuni [17], Maqasid Syariah are the objectives of the Shari'ah behind a provision, and the purpose of a provision is to realize those objectives for the good and benefit of mankind. Maqasid Syariah can also be interpreted as realizing the existence of benefits for the good of human beings by trying to implement them into reality and preserve it from any destruction and destruction. [18]. Al-Yubi [19] also defines the Maqasid Syariah as wisdom and syari maintains it in the legislation either in general or specifically to realize the welfare and goodness of mankind.

\subsection{Hifz an-Nafs, Hifz al- 'Aql dan Hifz al-Mal}

In the debate related to Maqasid Syariah, as-Syatibi divides its breakdown into three main bases namely aldaruriyyat (urgent need), al-hajiyyat (will) and altahsiniyyat (improvement). Then, the details of aldaruriyyat or also referred to as Maqasid al-Khamsah, Kulliyat al-Khamsah and al-daruriyyat al-Khamsah are divided into five, namely ad-Din (religion), an-Nafs (life), al-'Aql (akal), an-Nasl (descent) and al-Mal (wealth) [20]. Menurut Al-Ghazali (1993), all acts that preserve the sustainability of these five elements of maqasid are considered maslahah, while actions that are capable of disrupting and harassing are referred to as mafsadah.

Among the examples of Shariah emphasizing hifz anNafs (care of life) is the provision of appropriate punishment that exists in Hudud, Qisas and Ta'zir. Later, the Shari'ah also emphasizes hifz al-'Aql (preservation of the mind) with the prohibition of drinking alcohol and intoxication. Apart from that, hifz al-Mal (custody of property) is one of the elements that is given attention by Syarak when it is prescribed on Muslims the obligation of zakat and the prohibition of stealing.

\section{THE RELATIONSHIP BETWEEN MAQASID SYARIAH AND LAW ENFORCEMENT}

Based on the Qur'an al-Karim and the Hadith of the Prophet Muhammad SAW and the history of Muslims, there are many events that illustrate the implementation of laws that are closely related to the Maqasid Syariah in solving a problem whether related to law, economy, administration and others. Some Islamic scholars and ulama 'put discussions related to law enforcement and administration under the title of Siasah Syar'iyyah because it is relevant with politic and governance.

According to Abd al-Rahman Taj [21], Siasah Syar'iyyah means all the laws and regulations that regulate the course of the country and govern the affairs of society in line with the Maqasid Syariah based on general rules and achieve its social goals even if the laws is not recorded with detailed arguments from the Qur'an and Sunnah". Siasah Syar'iyyah is the action of the government based on maslahah in matters that have no specific text and most matters yang tidak kekal dalam 
which does not remain in one state only and can change according to changes in time, place, circumstances, situations, and human interests [22]. In addition, Muhammad Na'im Yasin [23] also wrote about the relationship between Siasah Syar'iyyah and Maqasid Syariah; "Siasah Syar'iyyah" is the administration of people's affairs carried out by Muslim leaders directly or through their representatives and guided by the general objectives of syariah (Maqasid Syariah) ". Siasah Syar'iyyah is "flexibility for the rulers" to implement things that can lead to good as long as they do not conflict with religious principles even if there is no specific evidence that allows it to be implemented [24].

According to Taj [21], among the events related to the enforcement of the law by the caliph Umar RA and indirectly grounding the Maqasid Syariah was when he created a departmental system of coordinating the salaries of government officials, construction of prisoners (prisons), freezing the distribution of land to the army by imposing kharaj (land tax) due to the addition of new areas and the number of Muslims. This effort is seen as a measure to increase national revenue to bear the rising cost of government defense (hifz al-Nafs), eradicate poverty (hifz al-Mal) and solve population problems (hifz al-Nasl).

\section{CONCLUSION}

A law is designed to make it easier for people to live a social life. The law was drafted taking into account the priority in preserving the Dharuriyyat al-Khams which are the five universal human interests according to the levels, starting with Hifz Al-Din (religious care), Hifz AlNafs (care of life), Hifz Al-Maal (care of property), Hifz Al-'Aql (care of the mind) and Hifz Al-Nasal (care of offspring). So, in the case of a drunk driver, it is very much related to Hifz Al-Nafs, Al-'Aql and Al-Mal. Emphasis on law enforcement is among the forms of education and resolution.

\section{REFERENCES}

[1] Al-Qayyim, I., I'lam Al-Muwaqqiin An Rabbil Alamin. Beirut: Dar Al-Kuttub Al-Ilmiyyah, 1991.

[2] Auda, J., Memahami Maqasid Syariah. Kuala Lumpur: PTS Islamika Sdn Bhd, 2014.

[3] Terengganu Strategic \& Integrity Institute (TSIS) and Ikatan Ilmuan Nasional, Kertas Cadangan Polisi Tangani Isu Pemandu Mabuk di Malaysia, 2014.

[4] Ismail, S. Z., Kemalangan Maut Jalanraya Menurut Perspektif Undang-Undang Islam dan Malaysia', Jurnal Syariah, 7(2), 1999, pp. 91-106.
[5] WHO, Fact Sheets on Sustainable Development Goals: Health Targets - Road Safety, 2017. https://www.euro.who.int/_data/assets/pdf_file/00 03/351444/3.6-Fact-sheet-SDG-Road-safetyFINAL-10-10-2017.pdf

[6] WHO, Global Status Report on Road Safety, 2013. http://www.who.int/about/licensing/copyright_for $\mathrm{m} / \mathrm{en} / \mathrm{index} . \mathrm{html}$

[7] WHO, Global Status Report on Road Safety, 2018.

[8] Harith, S. H., \& Mahmud, N. Human risk factors and road accident causation among motorcyclists in Malaysia: A review article. Proceedings of the International Conference on Industrial Engineering and Operations Management, 2018-March, pp. 2202-2209.

[9] Mahat, N., Jamil, N., \& Raseli, S. S., Analysing Road Accident Triggers in Malaysia By Using Analytical Hierarchy Process. 3(2), 2020, pp. 118-125.

[10] Abdelfatah, A., Traffic Fatality Causes and Trends in Malaysia. In Malaysia Sustainable Cities Program, 2016 https://doi.org/10.1016/j.procs.2017.05.379\%0Ahtt ps://scienceimpact.mit.edu/sites/default/files/docu ments/Abdelfatah.pdf

[11] Ramlan Mohd Arshad, M., Omar, M., \& Afiqah Shahdan, N., Alcoholism among Youth: A Case Study in Kuala Lumpur, MalaysiaAlcoholism among Youth: A Case Study in Kuala Lumpur, Malaysia. International Journal of Culture and History (EJournal), 2015.

[12] Isah, N., Mohd Soid, N. F., Mohd Jawi, Z., Mohamed, N., \& Awang, A., Probing the effectiveness of 'OP Selamat' in creating the perception of being caught among road users in Malaysia. Journal of Advanced Vehicle System, 3(1), 2016, pp. 23-29. http://www.akademiabaru.com/doc/ARAVSV3_N 1_P23_29.pdf

[13] Akta Pengangkutan Jalan, 1987. Malaysia.

[14] Sinar Harian, Dewan Negara lulus RUU Pengangkutan Jalan (Pindaan) 2020.

[15] Teuku Iskandar et al. Kamus Dewan, (edisi ketiga), Kuala Lumpur: Dewan Bahasa DanPustaka, cet. 5, 2000, pp. 939.

[16] Mahmood Zuhdi Abdul Majid, Sejarah Pembinaan Hukum Islam, Jabatan Penerbitan Universiti Malaya: Kuala Lumpur, Edisi 2, 1992, pp. 2.

[17] Al-Raisuni, Aḥmad. Naẓariyyāt Al-Maqāsid 'Ind Al-Imām Al-Shātibiy. Virginia: The International Institute of Islamic Thought, 1995. 
[18] Abd al-Karim Zaydan. al-Wajiz Fi Usul al-Fiqh. Cetakan Pertama. Midan al-Sayyidah Zaynab: Dar al-Tawzi' Wa al-Nashr al-Islamiyyah, 1993.

[19] Muhammad Said al-Yubi, Maqasid al-Syari'ah alIslamiyyah $\mathrm{Wa}$ 'Alaqatuha $\mathrm{Bi}$ al-Adillah alSyar'iyyah, Riyadh: Dar al-Hijrah, 1998, pp. 37.

[20] Saifuddin al-Amidi, Al-Ihkam fi Usul al-Ahkam, (Cairo, Muassasah al-Halabi), Jil. 2, 1976, pp. 48

[21] Taj, Abd. Al-Rahman, Al-Siyasah al-Syar'iyyah wa al-Fiqh al-Islami, Ali Ahmad alKhatib (edit), Jami'ah al-Azhar, 1995.

[22] Utwah, Abd. al-Al Ahmad, Al-Madkhal Ila alSiyasah al-Syar'iyyah. Arab Saudi: Jami'ah Imam al-Saud, t.t.

[23] Shukeri Mohammad, Al-Siyasah al-Syar'iyyah wa Qawa'iduha Fi al-Iqab al-Ta'ziri, Tesis M.A. alJamiah al-Urduniyyah, 1994.

[24] Bahnasi, Ahmad Fathi. Al-Siyasah al-Jina'iyyah Fi al-Syari'ah al-Islamiyyah. Beirut: Dar al-Shuruq, 1983. 